\title{
Relationship between multi-scale climate factors and performance of ecological engineering on the Loess Plateau, China
}

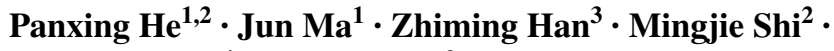 \\ Dongxiang $\mathrm{Xu}^{4} \cdot$ Zongjiu Sun $^{2}$
}

Received: 29 January 2021 / Accepted: 24 March 2021 / Published online: 29 April 2021

(C) The Author(s) 2021

\begin{abstract}
The long-term "Grain-to-Green Program" (GGP) on China's Loess Plateau is a major global ecological engineering project which has significantly boosted vegetation renewal. Some studies have found that the rate of restoration is quite rapid during the implementation of ecological engineering, however, the influence of multi-scale climatic conditions on the performance of ecological engineering is unclear. In this study, multiple sources of remote sensing data were used to estimate the dynamics of vegetation structural and functional indicators, water-related local climatic factors, and atmospheric circulation factors. These datasets
\end{abstract}

Project funding The work was supported by the Natural Science Foundation of China (41601181) and the Scientific Research Program of Shanghai Science and Technology Commission (20DZ1204702).

The online version is available at http://www.springerlink.com.

Corresponding editor: Tao Xu.

Jun Ma

ma_jun@fudan.edu.cn

1 Ministry of Education Key Laboratory for Biodiversity, Science and Ecological Engineering, National Observations and Research Station for Wetland Ecosystems of the Yangtze Estuary, School of Life Sciences, Fudan University, Shanghai 200438, People's Republic of China

2 Ministry of Education Key Laboratory for Western Arid Region Grassland Resources and Ecology, College of Grassland and Environment Sciences, Xinjiang Agricultural University, Urumqi 830052, People's Republic of China

3 State Key Laboratory Base of Eco-Hydraulic Engineering in Arid Areas, Xi' an University of Technology, Xi'an 710077, People's Republic of China

4 School of Earth and Environmental Sciences, University of Queensland, St Lucia 4072, Australia were also used to detect possible causes for vegetation restoration on the Loess Plateau over the past 20 years. The results show that widespread increases in rates of normalized difference vegetation indexes (NDVI), leaf area indexes (LAI), gross primary production (GPP), and aboveground biomass carbon (ABC) during 2000-2016 were significantly higher than before 2000. GPP was significantly correlated with rainfall and surface runoff on a monthly scale, and there were significant positive correlations between GPP and atmospheric circulation. Our results demonstrate that both vegetation structural and functional indicators rapidly increase, and ecological engineering greatly accelerated vegetation restoration after 2000. Local climatic conditions and atmospheric circulation patterns enhance vegetation growth and impact of ecological engineering.

Keywords Vegetation restoration - Ecological engineering · Water-related climatic factors · Atmospheric circulation and sunspot $\cdot$ Loess Plateau

\section{Introduction}

Restoration of vegetation effectively reduces soil erosion and improves ecological and environmental quality on a site (Fu et al. 2017). Climate change and human activities have a profound impact on the planet's vegetation and sustainability of ecosystems (Jiang et al. 2016), especially in arid and semi-arid areas which account for about $41 \%$ of the Earth's land surface and support $38 \%$ of the human population (Kaptue et al. 2015; Li et al. 2016). These regions are more ecologically fragile and more sensitive to climate change and human activities (Allan et al. 2013), and protecting their environment health is challenging. In China, many vegetation restoration projects are considered as 
'super-engineering' activities and are among the largest conservation and afforestation projects in history (Moore et al. 2016; Xu et al. 2017).

The Loess Plateau in China's arid and semi-arid regions, is a fragile and ultra-sensitive area because of its scarcity of water, high rates of soil erosion, and intense anthropogenic activities (Feng et al. 2013; Yu et al. 2018). Since 2000, a large-scale restoration project has been implemented on the Loess Plateau (Sun et al. 2015) which has resulted in a large increase in vegetation cover. The "Grain to Green Program" is a mega project to enhance the quality of the natural environment in the area. With the support of this greening policy, vegetation cover increased by about $28 \%$ during 1999-2013 (Chen et al. 2015).This led to a series of positive improvements in environmental conditions such as controlling soil erosion, preventing desertification (Ning et al. 2015), intercepting rainfall (Sun et al. 2015), cooling surface temperatures (Peng et al. 2014), and improving carbon sequestration (Gao et al. 2017).

Although vegetation restoration was greatly enhanced by this ecological project, it also benefited from changes to local and global climates. Numerous studies using satellite data have highlighted the relationship between climate and changes in vegetation cover and found that the growth of vegetation on the Loess Plateau is closely related to precipitation and temperature (Zhai et al. 2015; Li et al. 2019). In particular, in arid and semi-arid regions, the abundance of light and heat energy can satisfy the needs of vegetation (Zheng et al. 2019); however, water is the most important limiting factor to vegetation restoration. Adequate water supplies may be more important than the implementation of the intensity in boosting the efficiency of vegetation restoration in ecologically vulnerable regions (Deng et al. 2016). Some studies have indicated that an increase in rainfall strengthens the photosynthetic capacity of plants and further promotes the renewal of vegetation (Sun et al. 2015). Therefore, effective management of water resources is essential for the successful implementation of ecological engineering on the Loess Plateau (Liang et al. 2015). Although recent research has confirmed the importance of ecological engineering, the significance of climatic factors in vegetation restoration still needs to be explored.

In addition, atmospheric circulation patterns such as the Arctic Oscillation (AO), the El Niño-Southern Oscillation (ENSO), and the Pacific Decadal Oscillation (PDO), and sunspots, are highly related to regional and local climates. They have been shown to affect global water vapor transport and redistribution (Huang et al. 2017), and temperature fluctuations (Horton et al. 2015), which thus affect local climate and vegetation growth (Cho et al. 2014; Li et al. 2015; Han et al. 2019a). Dillon and Rundel (1990) studied the response of vegetation in the African desert in the 1982-1983 ENSO and found that vegetation dynamics was closely related to the event. Spatial patterns of the normalized difference vegetation index (NDVI) are closely linked to El Niño over Eurasia, and atypical temperature drops due to El Niño will significantly inhibit the growth of spring plants ( $\mathrm{Li}$ et al. 2017). Cho et al. (2014) found that $17 \%$ of the variation of vegetation in spring is also caused by the change of the Arctic Oscillation in high latitude areas. Although the effect of teleconnection factors on vegetation growth has been confirmed, it is important to explore whether multiple teleconnection factors have an impact on vegetation restoration on the Loess Plateau.

In this study, multiple satellite-based remote sensing data, including optical and microwave data, were selected to explore the dynamic of vegetation structural indexes, NDVI and leaf area index (LAI) and functional indexes such as gross primary productivity (GPP) and aboveground biomass carbon (ABC). In addition, the relationships between vegetation indexes and environmental factors, namely rainfall, soil moisture, surface runoff, and multiple atmospheric circulation indexes, were also explored. The primary objectives of this study were: (1) to explore how vegetation structure and function were restored on the Loess Plateau since 2000; and, (2) to detect possible multi-scale climatic factors for vegetation restoration on the Loess Plateau.

\section{Materials and methods}

\section{Study area}

The Loess Plateau is the largest loess deposit in the world and is located in the geometric center of China. It extends across $33^{\circ} 43^{\prime}-41^{\circ} 16^{\prime} \mathrm{N}$ and $100^{\circ} 54^{\prime}-114^{\circ} 33^{\prime} \mathrm{E}$ and covers an area of $62.14 \times 10^{4} \mathrm{~km}^{2}$ (Fig. 1). It has an average altitude of $1411 \mathrm{~m}$ a.s.1. with a warm temperate zone from south to north. Precipitation of the study area decreases from southeast to northwest with typical continental rainfall characteristics. Annual rainfall in most areas is approximately $400 \mathrm{~mm}$, the rainy season is concentrated but annual variability is high. A dry climate with high evaporation and a short frost-free period, coupled with frequent natural events such as strong winds and frost, result in stressful environmental conditions for vegetative growth. In addition, due to aggressive human activities, including excessive land use over a long time, vegetative cover is low and soil erosion severe. The vegetation is mainly crops, grasslands and forest (Fig. 1b).

\section{Climate data}

In order to explore the variability of water conditions on the Loess Plateau, the dynamics of precipitation, soil moisture, and surface runoff since 2000 were analyzed. The CHIRPS 

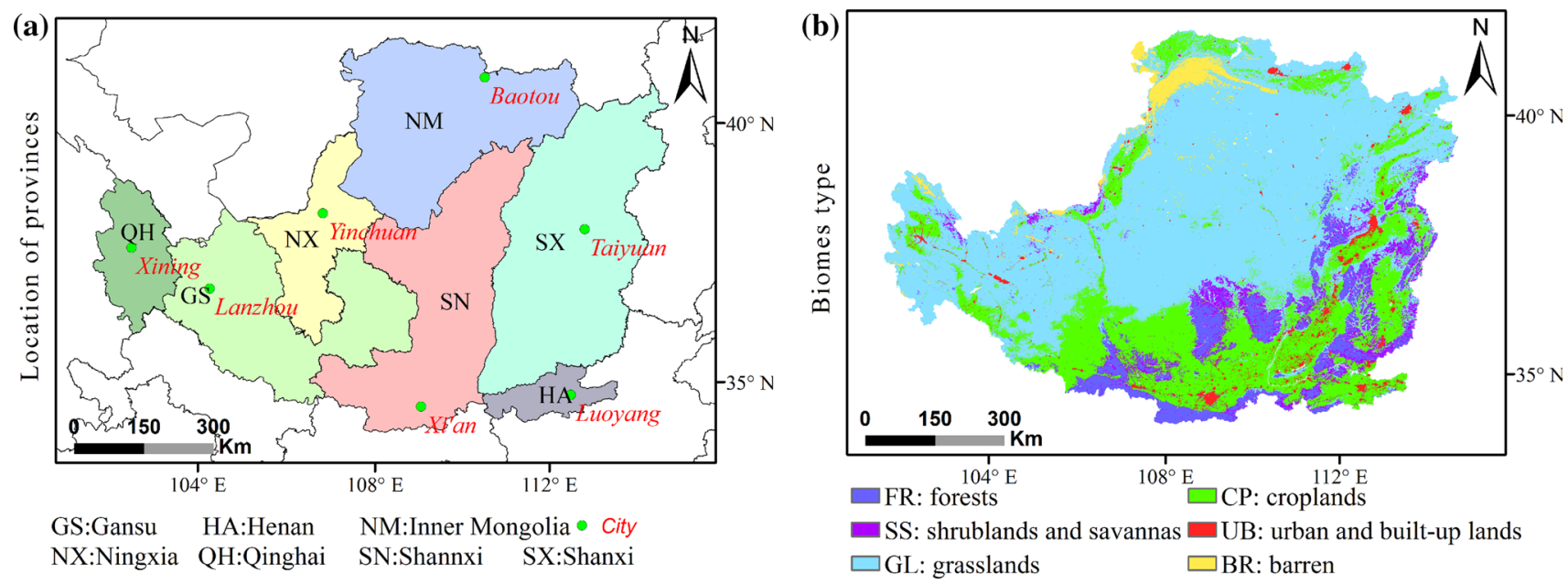

Fig. 1 Location and vegetation type on the Loess Plateau; a Provinces; $\mathbf{b}$ vegetation types; [The vector profile of the provinces is provided by the National Bureau of Surveying and Mapping Geographic Information, and the vegetation type is from MCD12Q1.]

v2.0 dataset was selected to provide gridded precipitation information (Funk et al. 2015). This provides raster data since 1981 with spatial resolutions of $0.25^{\circ}$ which can be obtained from http://chg.geog.ucsb.edu/data/chirps/.

Rainfall data since the 1980s from the meteorological stations of the China Meteorological Administration were also used in this study. The grid rainfall product based on meteorological observation can be obtained from the website http://www.nmic.cn/site/showSubject/id/46.html. The rainfall data of the stations around the Loess Plateau was used to spatially interpolate via the thin plate spline (TPS) method on ANUSPLIN software (Hutchinson 1995), and to further generate monthly rainfall grid data with a horizontal resolution of $0.5^{\circ}$ during $1982-2016$. In addition, in order to be consistent with the resolution of CHIRPS rainfall, the final rainfall data were re-sampled into $0.25^{\circ}$ resolution through the nearest neighbor method.

The Global Land Evaporation Amsterdam Model (GLEAM) for evapotranspiration and soil moisture estimated from satellite data was used. The latest GLEAM V3 provides a modified formula for evaporative stress and provides an advanced soil moisture data assimilation method (Martens et al. 2017). The global dataset on land evapotranspiration and soil moisture is available on the website www. gleam.eu which includes research on large-scale hydrological, climatic and terrestrial atmospheric feedback. In addition, GLEAM_surf and GLEAM_root provide data for soil moisture on the surface and roots, respectively, and total soil moisture can be obtained by adding GLEAM_surf and GLEAM_root together.

Runoff from the GLDAS-Noah, which provides a $0.25^{\circ}$ global grid (http://disc.sci.gsfc.nasa.gov/hydrology/dataholdings), was used in this paper. The Global Land and Data Assimilation System (GLDAS) product set is based on satellite and station data and combines advanced land and surface models and data assimilation techniques, surface states and fluxes.

In order to compare different types of water-related climatic factors with vegetation status, the Z-Score method was used to convert annual CHIRPS v2.0 rainfall, weather station rainfall, soil moisture, and runoff data during 2000-2016 of different magnitudes into the same size. This analysis used the Z-Score value to ensure comparability of all climate variables.

\section{Atmospheric circulation data}

In order to identify the relationship between atmospheric circulation patterns and vegetation restoration on the Loess Plateau, monthly Arctic Oscillation, El Niño-Southern Oscillation, and Pacific Decadal Oscillation data between January 2000 and December 2016 were used. Arctic Oscillation data was acquired from the NOAA National Climatic Data Center (http://www.ncdc.noaa.gov/teleconnections/ao. php). El Niño-Southern Oscillation data was obtained from the NOAA Earth System Research Laboratory (http://www. esrl.noaa.gov/psd/data/correlation/nina34.data) which provides Nino 3.4 Index. For the Pacific Decadal Oscillation, its monthly data were procured from the NOAA Earth System Research Laboratory (http://www.esrl.noaa.gov/psd/data/ correlation/amon.us.long.data).

\section{Vegetation indexes, GPP, and $\mathrm{ABC}$ dataset}

Gridded vegetation indexes (NDVI and LAI) and carbon sequestration indicators (GPP and $\mathrm{ABC}$ ) were selected to represent the process of vegetation renewal. Annual and monthly NDVI data from the SPOT VEGETATION was 
obtained at $1 \mathrm{~km}$ resolution, and 16 NDVI images of the year and 192 NDVI images of the month, respectively, from Resource and Environment Science and Data Center (http://www.resdc.cn/doi/doi.aspx?doiid=49). The latest updated Global Inventory Modelling and Mapping Studies (GIMMS)-3 g version 4 LAI data at $1 / 12 \times 1 / 12^{\circ}$ resolution (Zhu et al. 2013) was used, and a total of 420 images used for further analysis during 1982-2016. The NDVI and LAI are both comprehensive indicators reflecting vegetation utilization of light energy and canopy structure.

Monthly and annual gross primary productivity (GPP) data 2000-2016 was derived from the satellite-based lightuse efficiency model (Vegetation Photosynthesis Model, VPM), which was produced using a combination of VPM algorithms and products such as Moderate Resolution Imaging Spectroradiometer (MODIS) reflectance product and National Centers for Environmental Prediction (NCEP) Reanalysis II climate data, providing $500 \mathrm{~m}$ resolution, 8-day synthetic products (Zhang et al. 2017). The latest VPM GPP data, using an advanced vegetation index gap-filling smoothing algorithm to process the $\mathrm{C} 3 / \mathrm{C} 4$ photosynthesis pathway separately, solves some key problems that affect the inaccuracy of GPP data and is a widely used and reliable parametric model to simulate gross primary production of ecosystems. The GPP data has been satisfactorily validated using the multiple observational gross primary productivity data (Zhang et al. 2016; Ma et al. 2018), and provided an alternative GPP (gross primary productivity) estimate for carbon cycle research. Similarly, the Z-Score method was used to convert the 2000-2016 GPP into the same magnitude with water-related factors, which ensures comparability of the gross primary productivity with all climate variables.

The vegetation optical depth (VOD) was used to estimate aboveground biomass carbon. This data is based on the land parameter retrieval model and input passive microwave observations from multiple sensors, including the special sensor microwave imager, Feng Yun-3B, and the WindSat (Liu et al. 2015). In addition, a cumulative distribution function matching method was used to merge the vegetation optical depth signals from different sensors (Liu et al. 2015) to retain the long-term trends and inter-annual variations of vegetation optical depth as accurately as possible. Recent studies indicate that the VOD is a key parameter that reflects vegetation growth and is sensitive to the moisture content of woody vegetation (Tian et al. 2017). It is usually retrieved by the microwave radiative transfer model and is less affected by the weather. At present, the vegetation optical depth has been widely used as vegetation index to estimate aboveground biomass carbon (Liu et al. 2015; Brandt et al. 2018). The change in aboveground biomass carbon is generally driven by woody plants and is appropriate to be used to detect the dynamic of woody biomass in the ecological engineering area (Tong et al. 2018). Therefore, the gridded vegetation optical depth at $0.25^{\circ}$ resolution (1992-2012) was used to convert it to aboveground biomass carbon following the approach by Tong et al. (2018) and Niu et al. (2019).

\section{Detection of vegetation restoration trends and breakpoints}

Linear regression was used to analyse the trend of indicators for vegetation structure (NDVI and LAI) and function (GPP and $A B C$ ), as well as water status (rainfall, soil moisture, and runoff). The slope values of the linear regression between each indicator and year were regarded as their trends. The calculation of the slope was determined by:

Slope $=\frac{n \times \sum_{i=1}^{n}\left(i \times V_{i}\right)-\sum_{i=1}^{n} i \sum_{i=1}^{n} V_{i}}{n \times \sum_{i=1}^{n} i^{2}-\left(\sum_{i=1}^{n} i\right)^{2}}$

Slope is the rate of change of each variable; $i$ is the year, $n$ the length of the study period, and $V_{\mathrm{i}}$ the Variable $(\mathrm{V})$ value for the $i$ year. In the analysis, a $t$-test was used to verify the significance of the correlation coefficient, for which a positive and negative slope indicates a positive or negative trend. Specifically, $P<0.1$ represents a correlation and $P<0.05$ a significant correlation.

To detect whether an abrupt change occurred in vegetation cover after the implementation of the restoration project, the Breaks For Additive Seasonal and Trend (BFAST) method was applied to compare the number of pixels and where the breakpoint was detected for time series LAI and $\mathrm{ABC}$ before the project (prior to 2000) and after the project (after 2000). The BFAST method was originally used to identify vegetation disturbance using remote sensing data (Verbesselt et al. 2010). It can decompose the integrated time series into three parts: trend, seasonality, and residual. This method can be directly used in the original image time series without an additional standardization operation, and the algorithm has been widely used to detect the major breakpoints of vegetation time series (de Jong et al. 2013; He et al. 2021). In this study, the accumulative curve and the spatial distribution of the breakpoints before and after the implementation of the project are also identified. The "harmonic" seasonal model was selected as the best fit for phenological changes of natural vegetation (Verbesselt et al. 2010). Based on the assumption that 30 months is a moving data window, the bandwidth parameter was set to 0.15 and the significance level in BFAST analysis set to 0.05 .

\section{Cross-wavelet transformation}

Cross-wavelet analysis was performed to explore the impact of atmospheric circulation on vegetation restoration. The combination of wavelet transforms and cross spectrum analysis constitutes cross- wavelet analysis, a method to analyze 
the correlation of two signals in the time-frequency domain (Hudgins and Huang 1996). The cross-wavelets describe the distribution of coupled information in this domain (Huang et al. 2017), and the cross-wavelet condensation spectrum can explore the cross-wavelets analysis in a low energy region more effectively, aiming at exploring their correlation in time-frequency domain from multi-time scale (Torrence and Compo 1998).

The cross-wavelet transformation in this study reflects the regions of the two sequences with the same energy spectrum after the wavelets transform to reveal the significance of the interaction in different frequency domains. The energy of the cross-wavelet power spectrum is strong, and the higher the spectrum value, the more significant the oscillation of the period through the reliability test. The cross-wavelet transformation of time series is expressed as:

$W_{x y}(a, \tau)=C_{x}(a, \tau) C_{y}^{*}(a, \lambda)$

where $C x(\alpha, \tau)$ represents the wavelet transform coefficient of $x(t)$, and $C y^{*}(\alpha, \tau)$ the complex conjugation of wavelet transform coefficients of $\mathrm{y}(\mathrm{t})$.
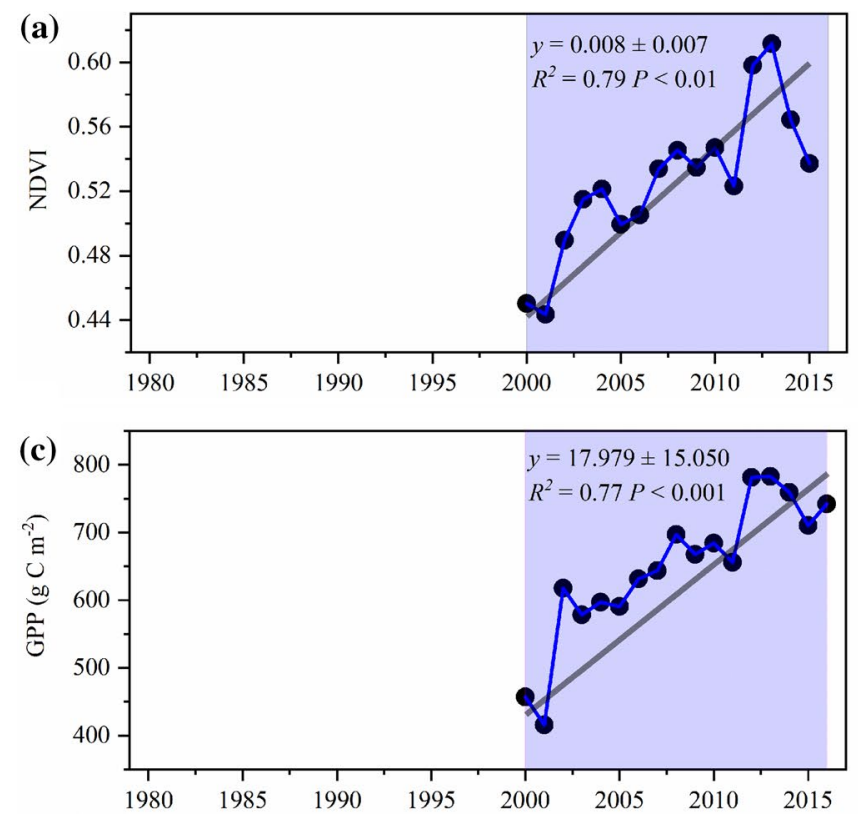

Fig. 2 Annual dynamics of the means of a NDVI, b LAI, $\mathbf{c}$ GPP, and d $\mathrm{ABC}$ for the Loess Plateau; the violet background is the implementation period of the ecological engineering project in that area; linear

\section{Results}

\section{Variation of vegetation status before and after the implementation of the project}

Significant linear increases were found for NDVI $\left(R^{2}=0.79\right.$, $P<0.01)$ and LAI $\left(R^{2}=0.79, P<0.01\right)$ after 2000 (Fig. $2 \mathrm{a}$ and $\mathrm{b}$ ), and their rates of increase were $0.008 \mathrm{a}^{-1}$ and 0.01 $\mathrm{m}^{2} \mathrm{~m}^{-2} \mathrm{a}^{-1}$, respectively. Similarly, the GPP and ABC also showed significant increases with the rates at $17.8 \mathrm{~g} \mathrm{C} \mathrm{m}^{-2}$ $\mathrm{a}^{-1}$ and $0.2 \mathrm{MgC} \mathrm{ha}^{-1} \mathrm{a}^{-1}$, respectively, in the same period (Fig. 2c and d). Vegetation structural and functional variables exhibited similar spatial patterns. High increasing values were generally distributed in the east and southern parts of the Loess Plateau, while lower values were found in the west and northwest. Moreover, the increases of NDVI (98\%), LAI (84\%), GPP (94\%), and ABC (99\%) after 2000 were identified for most areas on the Loess Plateau (Fig. 3). In particular, the percentage of the significantly increased trends for NDVI, LAI, GPP, and ABC were $63 \%, 79 \%, 71 \%$, and $82 \%$, respectively.

The changes of LAI $\left(0.002 \mathrm{~m}^{2} \mathrm{~m}^{-2} \mathrm{a}^{-1}\right)$ and ABC $\left(-0.06 \mathrm{Mg} \mathrm{C} \mathrm{ha}^{-1} \mathrm{a}^{-1}\right)$ before 2000 were significantly $(P<0.05)$ lower than those after 2000 of $0.01 \mathrm{~m}^{2} \mathrm{~m}^{-2} \mathrm{a}^{-1}$ and $0.18 \mathrm{Mg} \mathrm{C} \mathrm{ha}^{-1} \mathrm{a}^{-1}$, respectively, (Fig. 4). Moreover, based on the BFAST analysis, the number of pixels with breakpoints for LAI increased from 1987 to 2009 , with $82 \%$ of the total number of breakpoints occurring after 2000 (Fig. 5a). Similarly, the number of pixels with breakpoints for $\mathrm{ABC}$
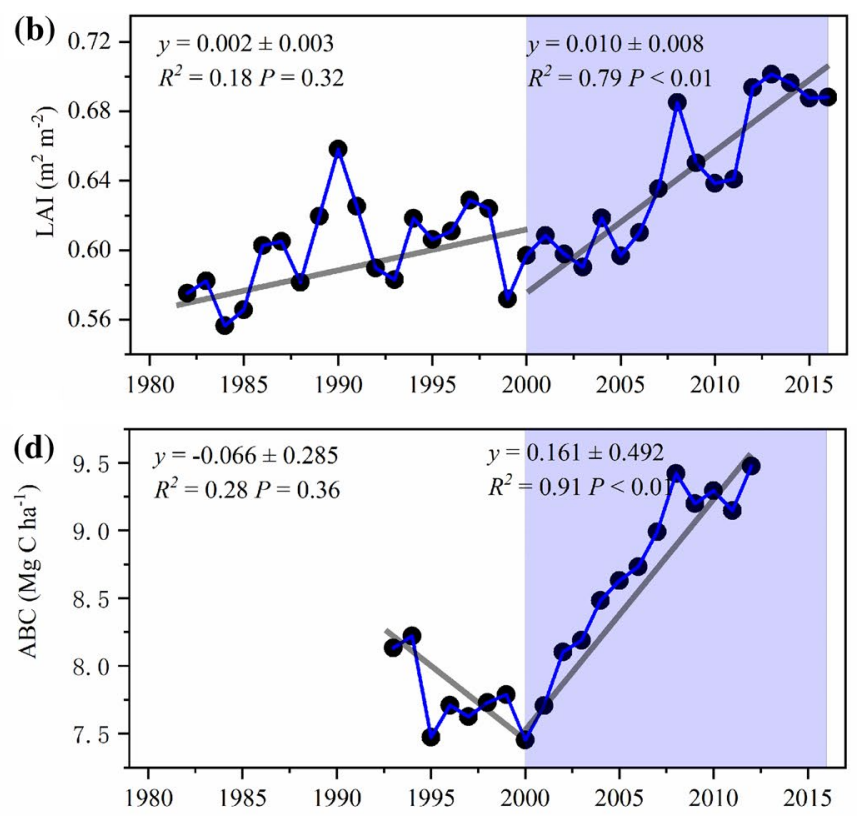

regressions were performed for these indicators at different periods before and after 2000 

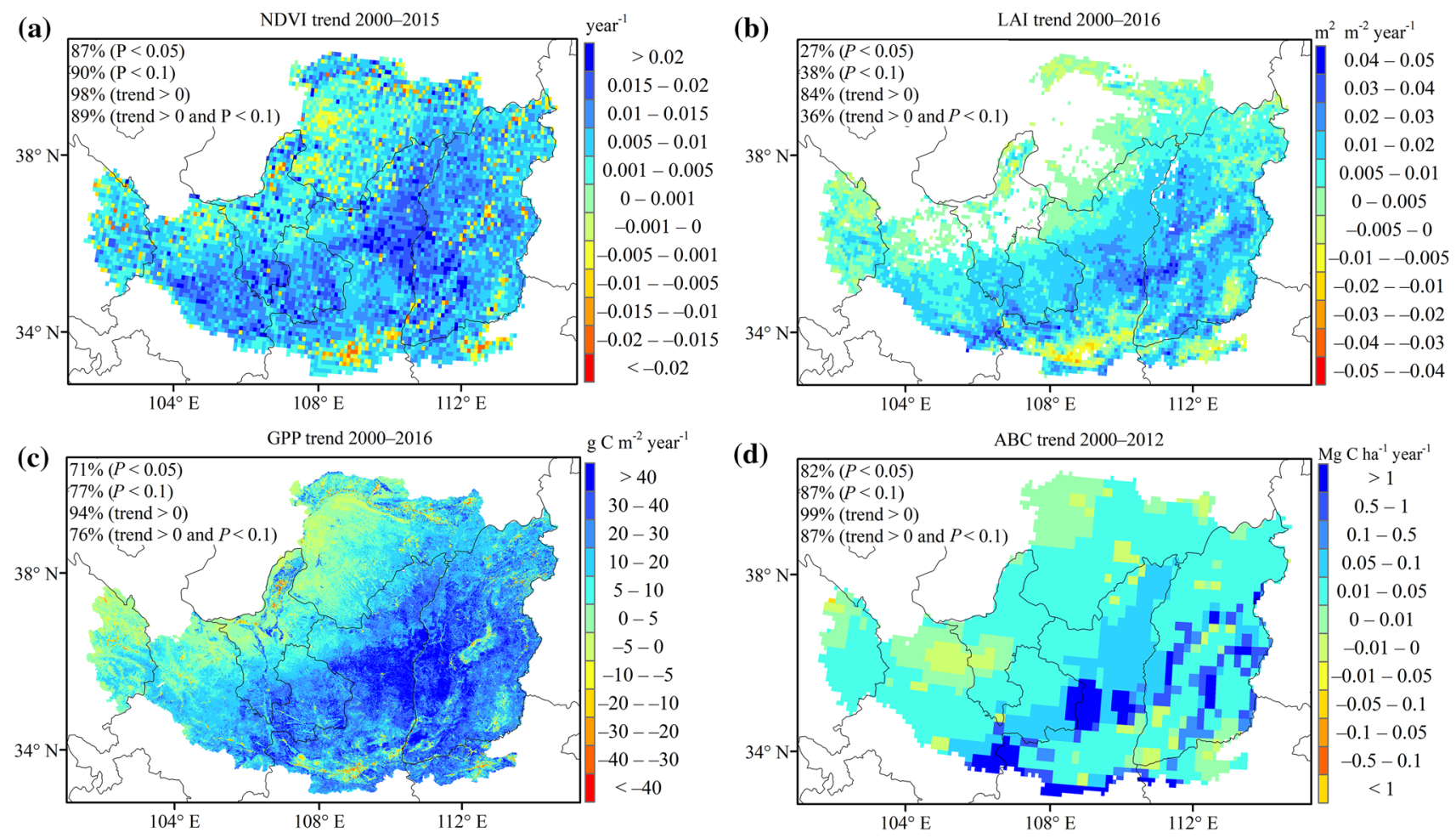

Fig. 3 Spatial distribution of the trends reflected by the slope of the linear regression of a NDVI; $\mathbf{b}$ LAI; c GPP, and $\mathbf{d}$ ABC for the Loess Plateau after 2000
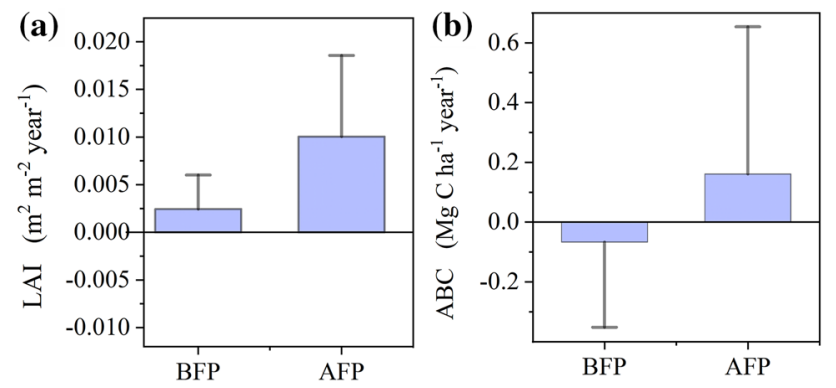

Fig. 4 Comparison of rates of change of a LAI and $\mathbf{b}$ ABC before and after the implementation of ecological engineering on the Loess Plateau; BFP: before implementation; AFP: after implementation
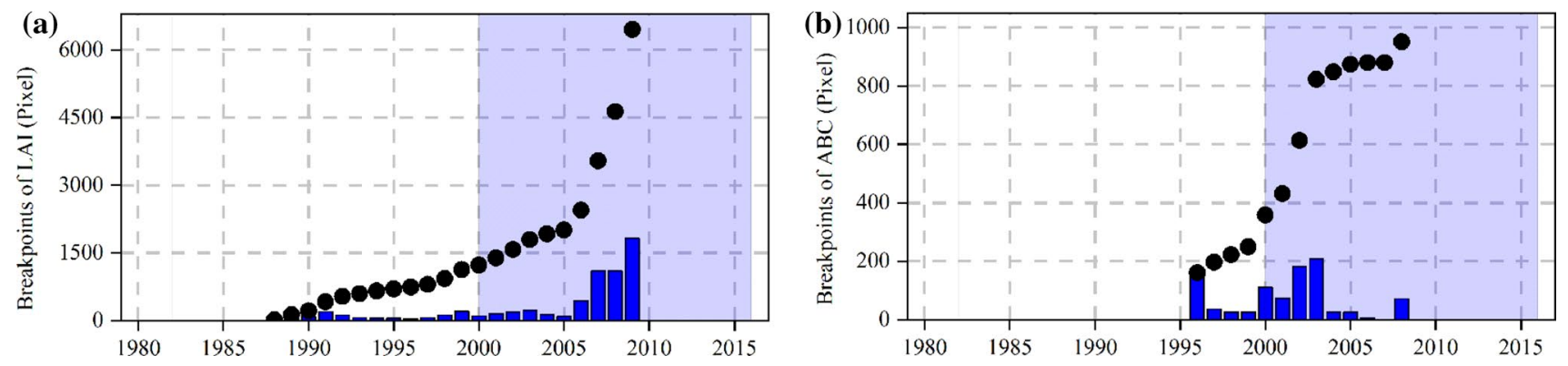

Fig. 5 Number of pixels with breakpoints for a LAI (1982-2016); b ABC (1992-2012) in BFAST analysis; blue bar refers to the number of breakpoints per year, and the black dots to the accumulative num-

increased from 1997 to 2008 , with $62 \%$ of the total occurring after 2000 (Fig. 5b).

\section{Variation of water-related climatic variables and their relationship to GPP}

There were general increases of CHIRPS rainfall (98\%), station observational rainfall (88\%), soil moisture $(82 \%)$, and surface runoff ( $82 \%$ ) during $2000-2016$ for most areas of the Loess Plateau (Fig. 6), with high values mainly in the central and eastern parts and low values in the south. The percentage of the significant increases for CHIRPS rainfall, station

ber; violet background is the implementation period of the ecological engineering 

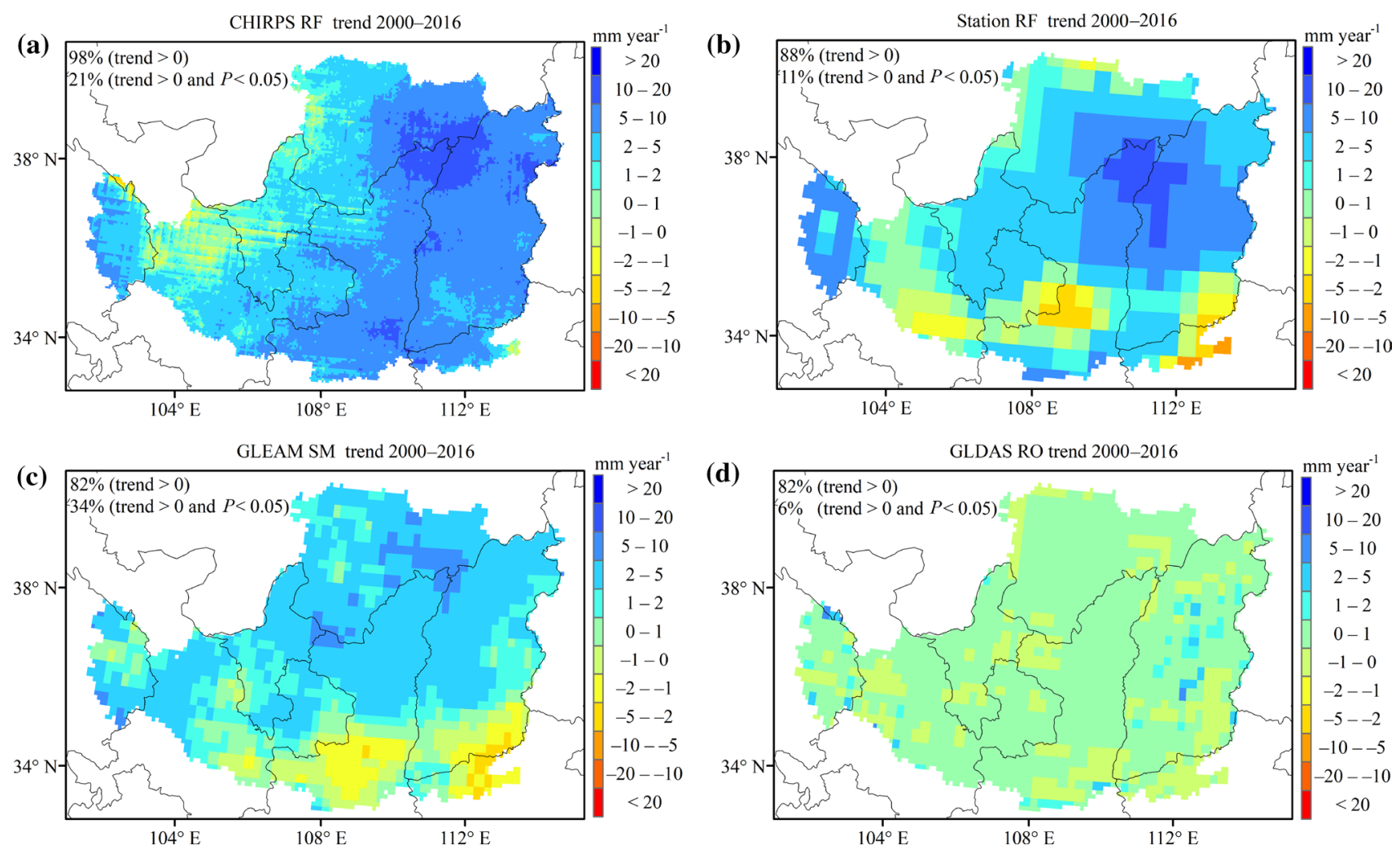

Fig. 6 Spatial distribution of linear trends reflected by the slopes of linear regressions of a CHIRPS RF; b station RF; c soil moisture, and d runoff during 2000-2016 in the Loess Plateau area

observational rainfall, soil moisture, and surface runoff were $21 \%, 11 \%, 34 \%$, and $6 \%$, respectively.

Annual GPP and water-related climate variables (rainfall, soil moisture, and surface runoff) all increased in the period
2000-2016 (Fig. 7a). Moreover, there were also significant correlations between GPP and CHIRPS rainfall $\left(R^{2}=0.79\right.$, $P=0.005)$, station observational rainfall $\left(R^{2}=0.76\right.$, $P=0.005)$, and surface runoff $\left(R^{2}=0.40, P=0.003\right)$ on a

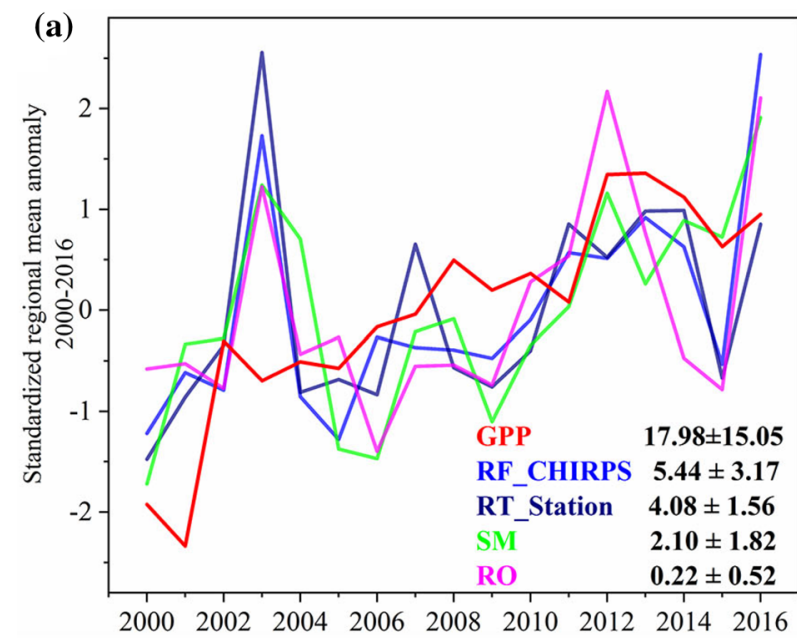

Fig. 7 Relationship between GPP and water-related climate variables showing annual linear trends; and monthly correlation coefficient $R$, $R^{2}$ and its $P$ value between GPP and a CHIRPS rainfall (RF), b station rainfall, $\mathbf{c}$ soil moisture (SM), $\mathbf{d}$ runoff (RO); GPP and climate (b)
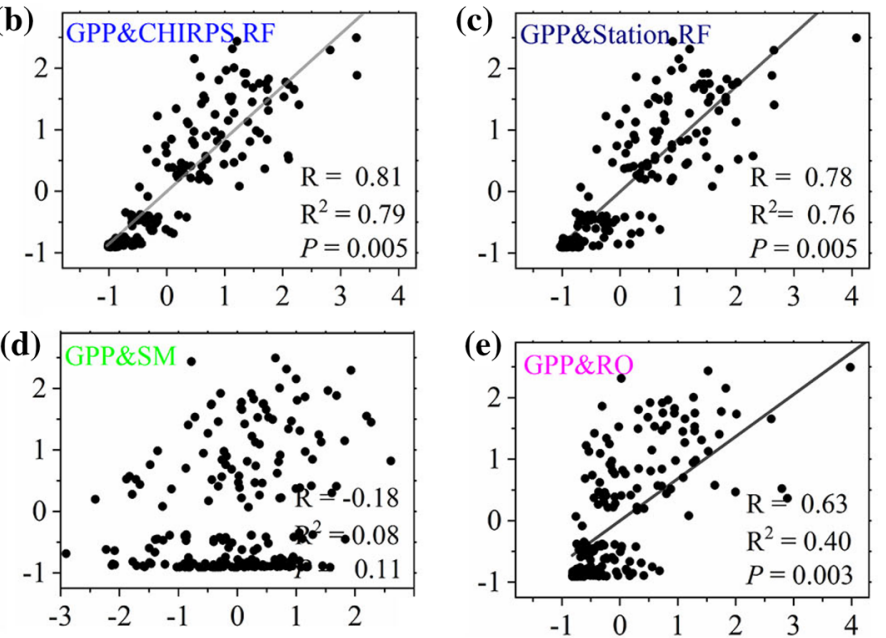

variables standardized owing to differences in magnitude; regional mean anomalies in GPP, RF, SM and RO ( GPP is $\mathrm{g} \mathrm{C} \mathrm{m}^{-2}$, RF, ET, $\mathrm{SM}$ and $\mathrm{RO}$ are in $\mathrm{mm}$ ) 
monthly scale over the same period. However, there was no significant correlation between GPP and soil moisture.

\section{Influence of teleconnection factors on gross primary product (GPP)}

There were significant positive correlations between GPP and AO, ENSO, and PDO during 2001-2016 on the Loess Plateau over a 10-14 month period (Fig. 8). Two significant signals in the correlation between GPP and AO were found 2009 to 2011 and in 2014. Compared with PDO, ENSO had a negative correlated cycle for 5 to 7 months between 2005 and 2015, and PDO had significant cycles in 2009 to 2011 and in 2013. However, GPP was negatively correlated with PDO and ENSO cycles for 5 to 7 months during 2005-2015. In addition, there was a significant signal for the correlation between GPP and sunspots in 2000-2006 and 2011-2014 for 10-12 months. Therefore, there is a high correlation between vegetation dynamics and atmospheric circulation index on the Loess Plateau, which indicates that vegetation is largely controlled by the background of climate change. In particular, the correlation between GPP and AO, ENSO, and PDO
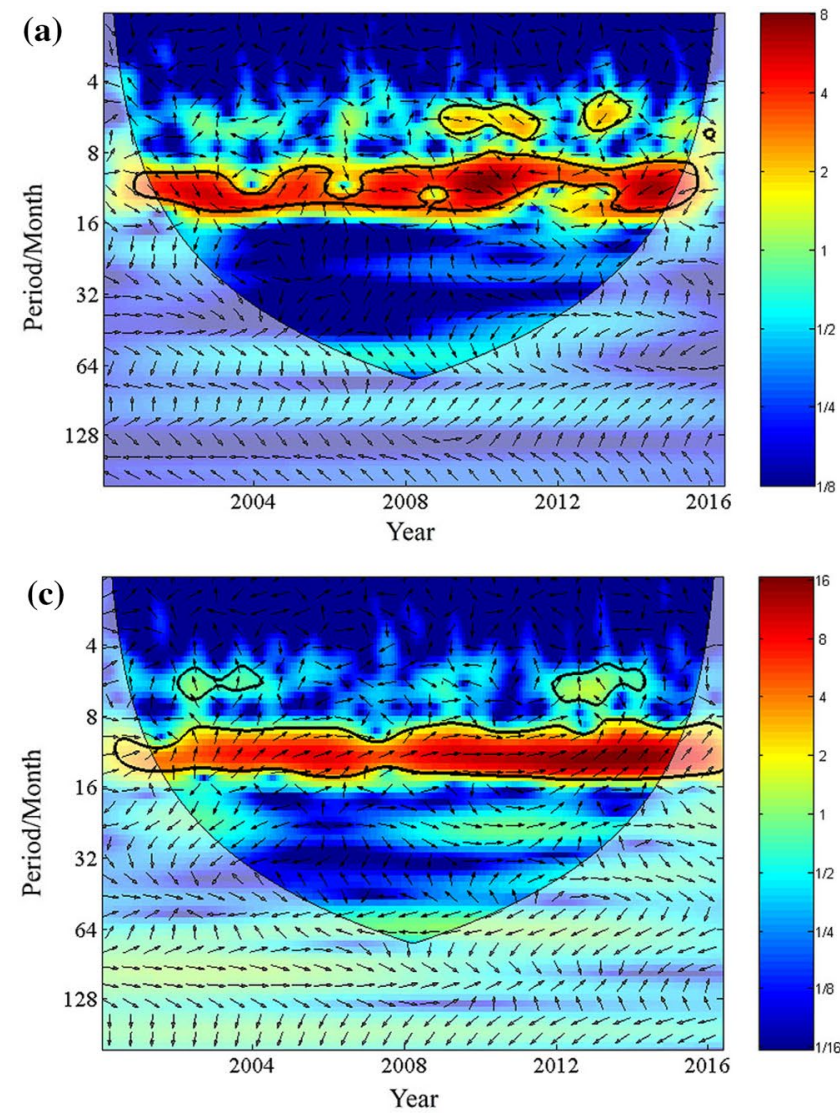

Fig. 8 Cross-wavelet transforms between monthly gross primary production and a AO; b ENSO; c PDO, and $\mathbf{d}$ sunspots for the period 2000-2016; coarse black line is a confidence interval of 95\% signifi- increased after 2009, which was significantly higher than over 2000-2008.

\section{Discussion}

\section{Vegetation restoration through ecological engineering}

In this study, relatively rapid and widespread restoration of vegetation for more than $80 \%$ of the ecological engineering projects was found from satellite-based evidence. The vegetation structural indicators, NDVI (normalized difference vegetation index) and LAI (leaf area index), are closely correlated with vegetation cover, and their significant increase after 2000 indicates that the ecological engineering on the Loess Plateau was a major factor. Increase rates of NDVI $\left(0.008 \mathrm{a}^{-1}\right)$ and LAI $\left(0.01 \mathrm{a}^{-1}\right)$ are similar and to results of previous studies (Sun et al. 2015; Zhu et al. 2016; Zheng et al. 2019), and demonstrates that our results are reasonable and reliable for detecting variations of vegetation structure on the Loess Plateau. In addition, the GPP (gross primary production) and $\mathrm{ABC}$ (aboveground biomass carbon) during
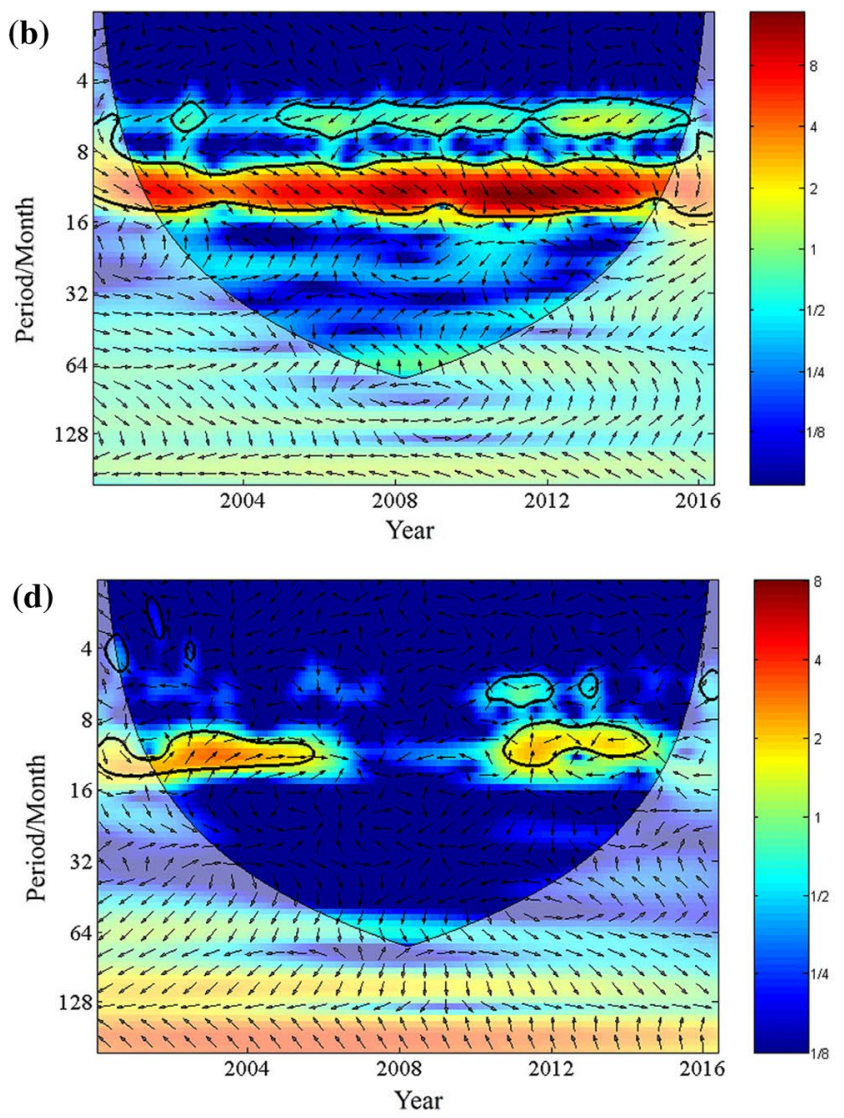

cance; arrows indicate the phase difference, to the right the change phase consistent, and to the left the opposite phase; the larger the wavelet coefficient, the more red meaning higher the correlation 
2000-2016 also showed increases and their rates were $17.8 \mathrm{~g}$ $\mathrm{C} \mathrm{m}^{-2} \mathrm{a}^{-1}$ and $0.2 \mathrm{MgC} \mathrm{ha}^{-1} \mathrm{a}^{-1}$, respectively. This indicates that a large amount of carbon dioxide was absorbed through photosynthesis and stored during the vegetation restoration process. Moreover, in the detection of breakpoints of vegetation structural and functional indicators, the shifting time for $\mathrm{LAI}$ and $\mathrm{ABC}$ coincided with the implementation of the ecological engineering projects, and the differences in the rate of change of LAI and $\mathrm{ABC}$ before and after 2000 were both significant. These facts further confirm that the results of the implementation of the ecological engineering projects were significant.

At present, ecological engineering projects such as the "Grain-to-Green Program", has resulted in significant achievements in reforestation on the Loess Plateau (Zhou et al. 2012; Wang et al. 2018), which has had positive effects on protecting the ecological environment and on carbon sequestration (Zhang and Shangguan 2016; Zhao et al. 2017). The implementation of this greening policy has had the greatest intensity and the most significant recovery, and a far-reaching impact (Ren et al. 2018). This program aimed at converting low-yield croplands or barren lands into forest, shrub, and grasslands, and was the largest ecological engineering program in history (Cao et al. 2007; Chen et al. 2019). Since 2000, the Chinese government has implemented new policies to reduce the intensity of timber harvesting and grazing, to restore the natural landscape of wastelands and degraded lands as quickly as possible (Niu et al. 2019), and to plant more drought-tolerant species in arid areas to combat desertification and improve the environment.

\section{Water conditions and atmospheric circulation jointly enhance the performance of ecological engineering}

Geographical conditions such as climatic, topography, and soil texture factors, are highly significant to vegetation growth (Meng et al. 2020; Sun et al. 2020); however, climate may be the most important factor. The relationship between climate and vegetation is a constant regardless of natural and human disturbances (Meng et al. 2020). In this study, rainfall, soil moisture, and surface runoff for most areas on the Loess Plateau show a positive increases after 2000 (Fig. 6). This means that our study area is gradually becoming wetter and gross primary productivity consequently increasing (Fig. 7). Considering that water resources are a limiting factor for vegetation growth in arid and semi-arid regions (Zhang and $\mathrm{Wu} 2020$ ), the increase in moisture is an important factor in enhancing vegetation growth (Zhou et al. 2014; Zhang et al. 2018) on the Loess Plateau. Short-term or long-term increases in rainfall were generally consistent with gradual temporal changes in runoff and surface soil moisture over the Loess Plateau ( $\mathrm{Li}$ et al. 2009), and the increase in rainfall has a positive feedback, leading to damper soils and greater surface runoff (Peng and Wang 2012; Feng et al. 2016). The improvement in water conditions is extremely beneficial to the growth of plants and it may well explain the dramatic change in vegetation on the Loess Plateau.

Besides local climate conditions, our results also show that multiple atmospheric circulation patterns had a significantly positive impact on GPP during 2000-2016 in the area. This is in line with previous studies which indicated that large- scale atmospheric circulation anomalies and sunspots are closely related to vegetation at regional and global scales (Horton et al. 2015; Huang et al. 2017). Arctic Oscillation is the main pattern of atmospheric circulation in the middle and high latitudes (Han et al. 2019b), and causes the anomalies in degree of cloud cover, temperature and rainfall through the influence on the mass, momentum and heat exchange of the atmosphere, which then influences the growth of plants. In addition, the impact of the El Niño-Southern Oscillation (ENSO) and the Pacific Decadal Oscillation (PDO) on vegetation may be caused by atmospheric teleconnection. As the Pacific Asia teleconnection can spread the impact of ENSO and PDO to Asia, Asian monsoons will be affected by the temperature and pressure of the Pacific Ocean. This will affect monsoon moisture and steam transport, causing climate anomalies (Xiao et al. 2015), and further affect the change in vegetation. In addition, sunspots were also identified as having a positive impact on the vegetation on the Loess Plateau during 2000-2016. Sunspot activity affects the solar radiation received by the earth, thus changing atmospheric pressure and temperature gradients, and affecting weather patterns (Soon et al. 2015), so that the ability of plants to obtain water changes, resulting in GPP increases.

Some studies have confirmed the complex relationship between atmospheric teleconnection and vegetation variations through changing regional temperatures, evapotranspiration, and soil moisture (Anyamba and Eastman 1996; Gong and Shi 2003; Zhao et al. 2019). Changing local climate may lead to biological consequences, including prolonging the growing season, promoting vegetation activities and increasing vegetation growth and carbon uptake. Therefore, largescale climate fluctuations affect vegetation growth by changing regional temperatures. The direct impact of atmospheric teleconnections on climate and their indirect impact on vegetation cover control the growth of plants. The cross-wavelet analysis in this study confirms that atmospheric circulation patterns (AO, ENSO, and PDO) and sunspots have a distinct impact on the vegetation of the Loess Plateau. Atmospheric circulation increases water vapor transport to the Loess Plateau, which increases the probability of water vapor falling to the surface, further increasing the frequency and intensity of rainfall and promoting vegetation restoration. In addition, changes in vegetation may also be affected by other factors such as global warming and gradually increasing $\mathrm{CO}_{2}$ 
concentrations (Poulter et al. 2014; Madani et al. 2018). The specific mechanisms needs further exploration.

\section{Conclusions}

In this study, the characteristic spatiotemporal distribution of vegetation structure and function, as well as climatic data, were analyzed over the entire Loess Plateau based on different satellite datasets. Both structural and functional indicators showed rapid increases, and the ecological engineering project greatly accelerated the renewal of vegetation on the Loess Plateau area after 2000. The area shows a gradual increase in moisture, which improves vegetation growth and enhances the performance of the ecological engineering project. In addition, patterns of atmospheric circulation also have a significant positive impact on the growth of plants on the Loess Plateau, and the impact has been further enhanced since 2009.

Acknowledgements We thank Yipu Wang in the School of Earth and Space Sciences, University of Science and Technology of China, and Dalei Hao in the Institute of Remote Sensing and Digital Earth, Chinese Academy of Sciences for their significant help in data processing and data analysis in this work.

Author's contributions Conceptualization, P.H. and J.M.; Data curation, P.H., Z.S., and J.M.; Formal analysis, P.H.; Funding acquisition, J.M. Investigation, P.H. and Z.S.; Project administration, J.M.; Resources, Z.H., and D.X., P.H.; Software, P.H. Z.H., and X.M.; Supervision, J.M., and Z.S.; Validation, P.H., and J.M.; Writing-original draft preparation, P.H., Z.S., and Z.H..; Writing-review and editing, P.H., J.M., M.S., and D.X.

Open Access This article is licensed under a Creative Commons Attribution 4.0 International License, which permits use, sharing, adaptation, distribution and reproduction in any medium or format, as long as you give appropriate credit to the original author(s) and the source, provide a link to the Creative Commons licence, and indicate if changes were made. The images or other third party material in this article are included in the article's Creative Commons licence, unless indicated otherwise in a credit line to the material. If material is not included in the article's Creative Commons licence and your intended use is not permitted by statutory regulation or exceeds the permitted use, you will need to obtain permission directly from the copyright holder. To view a copy of this licence, visit http://creativecommons.org/licenses/by/4.0/.

\section{References}

Allan JD, McIntyre PB, Smith SD, Halpern BS, Boyer GL, Buchsbaum A, Burton GA, Campbell J, Chadderton WL, Ciborowski JJ, Doran PJ, Eder T, Infante DM, Johnson LB, Joseph CA, Marino AL, Prusevich A, Read JG, Rose JB, Rutherford ES, Sowa SP, Steinman AD (2013) Joint analysis of stressors and ecosystem services to enhance restoration effectiveness. Proc Natl Acad Sci USA 110:372-377. https://doi.org/10.1073/pnas.1213841110
Anyamba A, Eastman R (1996) Interannual variability of NDVI over Africa and its relation to El Niño/Southern Oscillation. Int J Remote Sens 17:2533-2548. https://doi.org/10.1080/0143116960 8949091

Brandt M, Wigneron JP, Chave J, Tagesson T, Penuelas J, Ciais P, Rasmussen K, Tian F, Mbow C, Al-Yaari A, Rodriguez-Fernandez N, Schurgers G, Zhang WM, Chang JF, Kerr Y, Verger A, Tucker C, Mialon A, Rasmussen LV, Fan L, Fensholt R (2018) Satellite passive microwaves reveal recent climate-induced carbon losses in African drylands. Nat Ecol Evol 2:827-835. https://doi.org/10. 1038/s41559-018-0530-6

Cao SX, Chen L, Xu CG, Liu ZD (2007) Impact of three soil types on afforestation in China's Loess Plateau: growth and survival of six tree species and their effects on soil properties. Landsc Urban Plan 83:208-217. https://doi.org/10.1016/j.landurbplan.2007.04.006

Chen C, Park T, Wang X, Piao SL, Xu B, Chaturvedi RK, Fuchs R, Brovkin V, Ciais P, Fensholt R, Tommervik H, Bala G, Zhu ZC, Nemani RR, Myneni RB (2019) China and India lead in greening of the world through land-use management. Nat Sustain 2:122-129. https://doi.org/10.1038/s41893-019-0220-7

Chen YP, Wang KB, Lin YS, Shi WY, Song Y, He XH (2015) Balancing green and grain trade. Nat Geosci 8:739-741. https:// doi.org/10.1038/ngeo2544

Cho MH, Lim GH, Song HJ (2014) The effect of the wintertime arctic oscillation on springtime vegetation over the northern high latitude region Asia-Pacific. J Atmos Sci 50:567-573. https:// doi.org/10.1007/s13143-014-0046-1

de Jong R, Verbesselt J, Zeileis A, Schaepman M (2013) Shifts in global vegetation activity trends. Remote Sens 5:1117-1133. https://doi.org/10.3390/rs5031117

Deng L, Wang KB, Li JP, Zhao GE, Shangguan ZP (2016) Effect of soil moisture and atmospheric humidity on both plant productivity and diversity of native grasslands across the Loess Plateau, China. Ecol Eng 94:525-531. https://doi.org/10.1016/j. ecoleng.2016.06.048

Dillon MO, Rundel PW (1990) The botanical response of the Atacama and Peruvian Desert floras to the 1982-83 El Niño event. Elsevier Oceanogr 52:487-504. https://doi.org/10.1016/S04229894(08)70047-3

Feng X, Fu B, Piao SL, Wang S, Ciais P, Zeng ZZ, Lu YH, Zeng Y, Li Y, Jiang XH, Wu BF (2016) Revegetation in China's Loess Plateau is approaching sustainable water resource limits. Nat Clim Chang 6:1019. https://doi.org/10.1038/nclimate3092

Feng XM, Fu BJ, Lu N, Zeng Y, Wu BF (2013) How ecological restoration alters ecosystem services: an analysis of carbon sequestration in China's Loess Plateau. Sci Rep 3:2846. https://doi.org/ 10.1038/srep02846

Fu BJ, Wang S, Liu Y, Liu JB, Liang W, Miao CY (2017) Hydrogeomorphic ecosystem responses to natural and anthropogenic changes in the Loess Plateau of China. Annu Rev Earth Planet Sci 45:223-243. https://doi.org/10.1146/annur ev-earth-063016-020552

Funk C, Peterson P, Landsfeld M, Pedreros D, Verdin J, Shukla S, Husak G, Rowland J, Harrison L, Hoell A, Michaelsen J (2015) The climate hazards infrared precipitation with stations-a new environmental record for monitoring extremes. Sci Data 2:150066. https://doi.org/10.1038/sdata.2015.66

Gao Y, Dang P, Zhao Z (2017) Effects of afforestation on soil carbon and its fractions: a case study from the Loess Plateau, China. J For Res 29:1291-1297. https://doi.org/10.1007/ s11676-017-0552-y

Gong DY, Shi PJ (2003) Northern hemispheric NDVI variations associated with large-scale climate indices in spring. Int J Remote Sens 24:2559-2566. https://doi.org/10.1080/0143116031000075107

He PX, Sun ZJ, Han ZM, Dong YQ, Liu HX, Meng XY, Ma J (2021) Dynamic characteristics and driving factors of vegetation 
greenness under changing environments in Xinjiang, China. Environ Sci Pollut Res 4:1-17. https://doi.org/10.1007/ s11356-021-13721-z

Han ZM, Huang SZ, Huang Q, Leng GY, Wang H, Bai QJ, Zhao J, Ma L, Wang L, Du M (2019a) Propagation dynamics from meteorological to groundwater drought and their possible influence factors. J Hydrol 578:124102. https://doi.org/10.1016/j.jhydrol. 2019.124102

Han ZM, Huang SZ, Huang Q, Leng GY, Wang H, He L, Fang W, Li P (2019b) Assessing GRACE-based terrestrial water storage anomalies dynamics at multi-timescales and their correlations with teleconnection factors in Yunnan Province, China. J Hydrol 574:836-850. https://doi.org/10.1016/j.jhydrol.2019.04.093

Horton DE, Johnson NC, Singh D, Swain DL, Rajaratnam B, Diffenbaugh NS (2015) Contribution of changes in atmospheric circulation patterns to extreme temperature trends. Nature 522:465. https://doi.org/10.1038/nature14550

Huang SZ, Li P, Huang Q, Leng GY, Hou BB, Ma L (2017) The propagation from meteorological to hydrological drought and its potential influence factors. J Hydrol 547:184-195. https://doi.org/10. 1016/j.jhydrol.2017.01.041

Hudgins L, Huang J (1996) Bivariate Wavelet Analysis of Asia Monsoon and ENSO. Adv Atmos Sci 13:299-312. https://doi.org/10. 1007/BF02656848

Hutchinson MF (1995) Interpolating mean rainfall using thin plate smoothing splines. Int J Geogr Inf Sci 9:385-403. https://doi.org/ 10.1080/02693799508902045

Jiang C, Wang F, Zhang HY, Dong XL (2016) Quantifying changes in multiple ecosystem services during 2000-2012 on the Loess Plateau, China, as a result of climate variability and ecological restoration. Ecol Eng 97:258-271. https://doi.org/10.1016/j.ecole ng.2016.10.030

Kaptue AT, Prihodko L, Hanan NP (2015) On regreening and degradation in Sahelian watersheds. Proc Natl Acad Sci USA 112:1213312138. https://doi.org/10.1073/pnas.1509645112

Li G, Sun SB, Han JC, Yan JW, Liu WB, Wei Y, Lu N, Sun YY (2019) Impacts of Chinese Grain for Green program and climate change on vegetation in the Loess Plateau during 1982-2015. Sci Total Environ 660:177-187. https://doi.org/10.1016/j.scitotenv.2019. 01.028

Li J, Fan K, Xu ZQ (2015) Links between the late wintertime North Atlantic Oscillation and springtime vegetation growth over Eurasia. Clim Dyn 46:987-1000. https://doi.org/10.1007/ s00382-015-2627-9

Li J, Fan K, Zhou LM (2017) Satellite observations of El Niño impacts on Eurasian spring vegetation greenness during the period 19822015. Remote Sens 9:628. https://doi.org/10.3390/rs9070628

Li S, Liang W, Fu BJ, Lu YH, Fu SY, Wang S, Su HM (2016) Vegetation changes in recent large-scale ecological restoration projects and subsequent impact on water resources in China's Loess Plateau. Sci Total Environ 569-570:1032-1039. https://doi.org/10. 1016/j.scitotenv.2016.06.141

Li Z, Liu WZ, Zhang XC, Zheng FL (2009) Impacts of land use change and climate variability on hydrology in an agricultural catchment on the Loess Plateau of China. J Hydrol 377:35-42. https://doi. org/10.1016/j.jhydrol.2009.08.007

Liang W, Bai D, Wang FY, Fu BJ, Yan JP, Wang S, Yang YT, Long D, Feng MQ (2015) Quantifying the impacts of climate change and ecological restoration on streamflow changes based on a Budyko hydrological model in China's Loess Plateau. Water Resour Res 51:6500-6519. https://doi.org/10.1002/2014WR016589

Liu YY, Dijk AIJMv, Jeu RAMd, Canadell JG, McCabe MF, Evans JP, Wang GJ (2015) Recent reversal in loss of global terrestrial biomass. Nat Clim Chang 5:470-474. https://doi.org/10.1038/ nclimate 2581
Ma J, Xiao XM, Zhang Y, Doughty R, Chen BQ, Zhao B (2018) Spatial-temporal consistency between gross primary productivity and solar-induced chlorophyll fluorescence of vegetation in China during 2007-2014. Sci Total Environ 639:1241-1253. https://doi.org/ 10.1016/j.scitotenv.2018.05.245

Madani N, Kimball JS, Ballantyne AP, Affleck DLR, Van Bodegom PM, Reich PB, Kattge J, Sala A, Nazeri M, Jones MO, Zhao M, Running SW (2018) Future global productivity will be affected by plant trait response to climate. Sci Rep 8:2870. https://doi.org/ 10.1038/s41598-018-21172-9

Martens B, Miralles DG, Lievens H, van der Schalie R, de Jeu RAM, Fernández-Prieto D, Beck HE, Dorigo WA, Verhoest NEC (2017) GLEAM v3: satellite-based land evaporation and root-zone soil moisture. Geosci Model Dev 10:1903-1925. https://doi.org/10. 5194/gmd-10-1903-2017

Meng XY, Gao X, Li SY, Lei JQ (2020) Spatial and temporal characteristics of vegetation NDVI changes and the driving forces in mongolia during 1982-2015. Remote Sens 12:603. https://doi. org/10.3390/rs12040603

Moore JC, Chen Y, Cui X, Yuan W, Dong W, Gao Y, Shi P (2016) Will China be the first to initiate climate engineering? Earths Future 4:588-595. https://doi.org/10.1002/2016ef000402

Ning TT, Liu WZ, Lin W, Song XQ (2015) NDVI variation and its responses to climate change on the Northern Loess Plateau of China from 1998 to 2012. Adv Meteorol 2015:1-10. https://doi. org/10.1155/2015/725427

Niu QF, Xiao XM, Zhang Y, Qin YW, Dang XH, Wang J, Zou ZH, Doughty RB, Brandt M, Tong XW, Horion S, Fensholt R, Chen C, Myneni RB, Xu WH, Di GZ, Zhou XM (2019) Ecological engineering projects increased vegetation cover, production, and biomass in semiarid and subhumid Northern China. Land Degrad Dev 30:1620-1631. https://doi.org/10.1002/ldr.3351

Peng SS, Piao S, Zeng Z, Ciais P, Zhou L, Li LZ, Myneni RB, Yin Y, Zeng H (2014) Afforestation in China cools local land surface temperature. Proc Natl Acad Sci USA 111:2915-2919. https:// doi.org/10.1073/pnas.1315126111

Peng T, Wang SJ (2012) Effects of land use, land cover and rainfall regimes on the surface runoff and soil loss on karst slopes in southwest China. CATENA 90:53-62. https://doi.org/10.1016/j. catena.2011.11.001

Poulter B, Frank D, Ciais P, Myneni RB, Andela N, Bi J, Broquet G, Canadell JG, Chevallier F, Liu YY, Running SW, Sitch S, van der Werf GR (2014) Contribution of semi-arid ecosystems to interannual variability of the global carbon cycle. Nature 509:600-603. https://doi.org/10.1038/nature13376

Ren ZP, Li ZB, Liu XL, Li P, Cheng SD, Xu GC (2018) Comparing watershed afforestation and natural revegetation impacts on soil moisture in the semiarid Loess Plateau of China. Sci Rep 8:2972. https://doi.org/10.1038/s41598-018-21362-5

Soon W, Connolly R, Connolly M (2015) Re-evaluating the role of solar variability on Northern Hemisphere temperature trends since the 19th century. Earth Sci Rev 8:409-452. https://doi.org/ 10.1016/j.earscirev.2015.08.010

Sun WY, Song XY, Mu XM, Gao P, Wang F, Zhao GJ (2015) Spatiotemporal vegetation cover variations associated with climate change and ecological restoration in the Loess Plateau. Agric For Meteorol 209-210:87-99. https://doi.org/10.1016/j.agrformet. 2015.05.002

Sun Y, Hou FJ, Angerer JP, Yi SH (2020) Effects of topography and land-use patterns on the spatial heterogeneity of terracette landscapes in the Loess Plateau. China Ecol Indic 109:105839. https:// doi.org/10.1016/j.ecolind.2019.105839

Tian F, Brandt M, Liu YY, Rasmussen K, Fensholt R (2017) Mapping gains and losses in woody vegetation across global tropical 
drylands. Glob Chang Biol 23:1748-1760. https://doi.org/10. $1111 /$ gcb.13464

Tong XW, Brandt M, Yue YM, Horion S, Wang KL, Keersmaecker WD, Tian F, Schurgers G, Xiao XM, Luo YQ, Chen C, Myneni R, Shi Z, Chen HS, Fensholt R (2018) Increased vegetation growth and carbon stock in China karst via ecological engineering. Nat Sustain 1:44-50. https://doi.org/10.1038/s41893-017-0004-x

Torrence C, Compo GP (1998) A practical guide to wavelet analysis. Bull Am Meteorol Soc 79:61-78. https://doi.org/10.1175/15200477(1998)079\%3c0061:APGTWA\%3e2.0.CO;2

Verbesselt J, Hyndman R, Newnham G, Culvenor D (2010) Detecting trend and seasonal changes in satellite image time series. Remote Sens Environ 114:106-115. https://doi.org/10.1016/j.rse.2009. 08.014

Wang XH, Wang BT, Xu XY, Liu T, Duan YJ, Zhao Y (2018) Spatial and temporal variations in surface soil moisture and vegetation cover in the Loess Plateau from 2000 to 2015. Ecol Indic 95:320 330. https://doi.org/10.1016/j.ecolind.2018.07.058

Xiao MZ, Zhang Q, Singh VP (2015) Influences of ENSO, NAO, IOD and $\mathrm{PDO}$ on seasonal precipitation regimes in the Yangtze River basin, China. Int J Climatol 35:3556-3567. https://doi.org/10. 1002/joc. 4228

Xu WH, Xiao Y, Zhang JJ, Yang W, Zhang L, Hull V, Wang Z, Zheng H, Liu J, Polasky S, Jiang L, Xiao Y, Shi X, Rao E, Lu F, Wang XK, Daily GC, Ouyang ZY (2017) Strengthening protected areas for biodiversity and ecosystem services in China. Proc Natl Acad Sci USA 114:1601-1606. https://doi.org/10.1073/pnas.16205 03114

Yu BW, Liu GH, Liu QS (2018) Effects of land use changes for ecological restoration on soil moisture on the Chinese Loess Plateau: a meta-analytical approach. J For Res 31:109-118. https://doi.org/ 10.1007/s11676-018-0760-0

Zhai J, Liu RG, Liu JY, Huang L, Qin YW (2015) Human-induced landcover changes drive a diminution of land surface albedo in the Loess Plateau (China). Remote Sens 7:2926-2941. https://doi. org/10.3390/rs70302926

Zhang MM, Wu XQ (2020) The rebound effects of recent vegetation restoration projects in $\mathrm{Mu}$ Us Sandy land of China. Ecol Indic 113:106228. https://doi.org/10.1016/j.ecolind.2020.106228

Zhang WM, Brandt M, Tong XY, Tian QJ, Fensholt R (2018) Impacts of the seasonal distribution of rainfall on vegetation productivity across the Sahel. Biogeosciences 15:319-330. https://doi.org/10. 5194/bg-15-319-2018

Zhang Y, Xiao XM, Jin C, Dong JW, Zhou S, Wagle P, Joiner J, Guanter L, Zhang YG, Zhang GL, Qin YW, Wang J, Moore B (2016) Consistency between sun-induced chlorophyll fluorescence and gross primary production of vegetation in North America. Remote Sens of Environ 183:154-169. https://doi.org/10.1016/j. rse.2016.05.015

Zhang Y, Xiao XM, Wu XC, Zhou S, Zhang G, Qin YW, Dong JW (2017) A global moderate resolution dataset of gross primary production of vegetation for 2000-2016. Sci Data 4:170165. https://doi.org/10.1038/sdata.2017.165

Zhang YW, Shangguan ZP (2016) The coupling interaction of soil water and organic carbon storage in the long vegetation restoration on the Loess Plateau. Ecol Eng 91:574-581. https://doi.org/ 10.1016/j.ecoleng.2016.03.033

Zhao AZ, Zhang AB, Lu CY, Wang DL, Wang HF, Liu HX (2017) Spatiotemporal variation of vegetation coverage before and after implementation of Grain for Green Program in Loess Plateau, China. Ecol Eng 104:13-22. https://doi.org/10.1016/j.ecoleng. 2017.03.013

Zhao J, Huang SZ, Huang Q, Wang H, Leng GY, Peng J, Dong HX (2019) Copula-based abrupt variations detection in the relationship of seasonal vegetation-climate in the Jing River Basin. China Remote Sens 11:1628. https://doi.org/10.3390/rs11131628

Zheng H, Lin H, Zhou WJ, Bao H, Zhu XJ, Jin Z, Song Y, Wang YQ, Liu WZ, Tang YK (2019) Revegetation has increased ecosystem water-use efficiency during 2000-2014 in the Chinese Loess Plateau: evidence from satellite data. Ecol Indic 102:507-518. https:// doi.org/10.1016/j.ecolind.2019.02.049

Zhou DC, Zhao SQ, Zhu C (2012) The Grain for Green Project induced land cover change in the Loess Plateau: a case study with Ansai County, Shanxi Province, China. Ecol Indic 23:88-94. https://doi. org/10.1016/j.ecolind.2012.03.021

Zhou LM, Tian YH, Myneni RB, Ciais P, Saatchi S, Liu YY, Piao SL, Chen HS, Vermote EF, Song CH, Hwang T (2014) Widespread decline of Congo rainforest greenness in the past decade. Nature 509:86-90. https://doi.org/10.1038/nature13265

Zhu ZC, Bi J, Pan YZ, Ganguly S, Anav A, Xu L, Samanta A, Piao SL, Nemani RR, Myneni RB (2013) Global data sets of vegetation leaf area index (LAI)3g and Fraction of Photosynthetically Active Radiation (FPAR)3g derived from Global Inventory Modeling and Mapping Studies (GIMMS) Normalized Difference Vegetation Index (NDVI3g) for the period 1981 to 2011. Remote Sens 5:927-948. https://doi.org/10.3390/rs5020927

Zhu ZC, Piao SL, Myneni RB, Huang MT, Zeng ZZ, Canadell JG, Ciais P, Sitch S, Friedlingstein P, Arneth A, Cao CX, Cheng L, Kato E, Koven C, Li Y, Lian X, Liu YW, Liu RG, Mao JF, Pan YZ, Peng SS, Peñuelas J, Poulter B, Pugh TAM, Stocker BD, Viovy N, Wang XH, Wang YP, Xiao ZQ, Yang H, Zaehle S, Zeng $\mathrm{N}$ (2016) Greening of the Earth and its drivers. Nat Clim Chang 6:791-795. https://doi.org/10.1038/nclimate3004

Publisher's Note Springer Nature remains neutral with regard to jurisdictional claims in published maps and institutional affiliations. 